\title{
Meteorological factors, COVID-19 cases, and deaths in top 10 most affected countries: an econometric investigation
}

\author{
Gagan Deep Sharma $^{1}$ (D) Sanchita Bansal ${ }^{1}$ (D) Anshita Yadav $^{1}$ (D) $\cdot$ Mansi Jain ${ }^{1}$ (D) Isha $_{\text {Garg }}{ }^{1}$ (D)
}

Received: 10 September 2020 / Accepted: 21 January 2021 / Published online: 5 February 2021

(C) The Author(s), under exclusive licence to Springer-Verlag GmbH, DE part of Springer Nature 2021

\begin{abstract}
This paper examines the nexus between the Covid-19 confirmed cases, deaths, meteorological factors, including an air pollutant among the world's top 10 infected countries, from 1 February 2020 through 30 June 2020, using advanced econometric techniques to address heterogeneity across the nations. The findings of the study suggest that there exists a strong crosssectional dependence between Covid-19 cases, deaths, and all the meteorological factors for the countries under study. The findings also reveal that a long-term relationship exists between all the meteorological factors. There exists a bi-directional causality running between the Covid-19 cases and all the meteorological factors. With Covid-19 death cases as the dependent variable, there exists bi-directional causality running between the Covid-19 death cases and Covid-19 confirmed cases, air pressure, humidity, and temperature. Temperature and air pressure exhibit a statistically significant and negative impact on the Covid-19 confirmed cases. Air pollutant PM2.5 also exhibits a significant but positive impact on the Covid-19 confirmed cases. Temperature indicates a statistically significant and negative impact on the Covid-19 death cases. At the same time, Covid-19 confirmed cases and air pollutant PM2.5 exhibit a statistically significant and positive impact on the Covid-19 death cases across the ten countries under study. Hence, it is possible to postulate that cool and dry weather conditions with lower temperatures may promote indoor activities and human gatherings (assembling), leading to virus transmission. This study contributes both practically and theoretically to the concerned field of pandemic management. Our results assist in taking appropriate measures in implementing intersectoral policies and actions as necessary in a timely and efficient manner.
\end{abstract}

Keywords COVID-19 $\cdot$ Temperature $\cdot$ Humidity $\cdot$ Air pressure $\cdot$ Wind speed $\cdot$ Meteorological factors $\cdot$ PM2.5

\section{Introduction}

Responsible Editor: Philippe Garrigues

Gagan Deep Sharma

angrishgagan@gmail.com

Sanchita Bansal

bansalsanchita@gmail.com

Anshita Yadav

anshitayadav7@gmail.com

Mansi Jain

guptamansi007@gmail.com

Isha Garg

ishagarg2206@gmail.com

1 University School of Management Studies, Guru Gobind Singh Indraprastha University, New Delhi 110078, India
Covid-19 not only is a serious concern for public health but also caused has a devastating socio-economic situation in the countries it invaded (Raza et al. 2020; Chakraborty and Maity 2020; Habib et al. 2020). The developing countries categorized by the slow growth rate, poor healthcare infrastructure, and large population (a majority of them living in extreme poverty) have been severely affected by the Covid-19 pandemic (Sharma et al. 2020b, c). The Covid-19 pandemic resulted in a substantial loss of human capital of the economy (Shahzad et al. 2020). It thus increased the total (public and private) expenditure on healthcare (Lee and McKibbin 2004). While causing immense damage to human life, it has significantly impacted economic and social life (Nakada and Urban 2020; Shehzad et al. 2020). To prevent the spread of the virus, countries have announced lock-down campaigns, blocking various economic activities, including airlines, transportation activities, and educational institutes (Meo et al. 2020). 
Most of the research work studying the impact of the Covid-19 has focused on China (Ma et al. 2020; Shi et al. 2020) and the USA (Bashir et al. 2020; Gupta et al. 2020), in particular. There is an immense need to investigate the impact of the virus on other countries. This study focuses on the top 10 adversely affected countries (as of 30 June 2020) (CNA 2020), including Brazil, Chile, India, Iran, Italy, Peru, Russia, Spain, the UK, and the USA. Since these countries include developed as well as developing countries, the results of the study are generalizable.

Epidemiological studies suggest that the spread of historical outbreaks, such as severe acute respiratory syndrome (SARS) and Middle East respiratory syndrome disease (MERS), has been altered by the environmental conditions (Méndez-Arriaga 2020). Casanova et al. (2010) explain that the dry and cold weather conditions facilitate the virus's transmission and survival. Since the coronavirus belongs to the same family and possesses symptoms like cold, cough, flu, and fever, it must be affected by weather conditions also. Therefore, it is imperative to study different factors, including humidity, temperature, wind speed, and air pressure, and their influence on Covid-19 cases. While most of the studies have investigated the impact of the Covid-19 period on air quality (Dutheil et al. 2020), this study investigates the impact of air quality on Covid-19 cases. Due to the non-availability of Air Quality Index (AQI) data on daily basis for the countries under study, we have used PM2.5 (one of the air pollutants) as a proxy for AQI. Thus, the variables used for this study include the daily number of Covid-19 cases and deaths, air pressure, relative humidity, average air temperature, wind speed, and particulate matter 2.5. The time-series graphs (annexure) for each of the variables per country depict that the number of confirmed cases during the period under study have been the highest for the USA, followed by Brazil and Russia; the number of deaths has been the highest in the USA in April and May, followed by Brazil in June; the temperature has been the highest in India in May, while Peru has also reported higher range of temperature for the period under study; the air pollutant PM2.5 is seen to be the highest in India followed by Iran, while the lowest range is observed to be in Brazil; the highest wind speed is observed in Iran in February followed with the USA in March; the air pressure has been quite similar in every month for each of the top 10 countries under study; the humidity has been highest in almost all the countries while Iran relatively reports the lowest humidity in June. Furthermore, Table 1 presents the latest data on the total number of cases and deaths in the ten countries under study, as of 16 November 2020.

This paper contributes to the existing body of literature in the following three ways. First, it is a comprehensive study considering variables that can potentially affect the transmission of coronavirus. The previous studies have suffered from omitted variable bias. However, Sarkodie and Owusu (2020)
Table 1 Number of total cases and total deaths in the ten countries under study, as on 16 November 2020

\begin{tabular}{llll}
\hline S No. & Affected country & Total cases & Total deaths \\
\hline 1 & USA & $11,475,609$ & 252,337 \\
2 & India & $8,873,994$ & 130,552 \\
3 & Brazil & $5,864,943$ & 165,858 \\
4 & Russia & $1,948,603$ & 33,489 \\
5 & Spain & $1,521,899$ & 41,253 \\
6 & UK & $1,390,681$ & 52,147 \\
7 & Italy & $1,205,881$ & 45,733 \\
8 & Peru & 937,011 & 35,231 \\
9 & Iran & 775,121 & 41,979 \\
10 & Chile & 532,604 & 14,863 \\
\hline
\end{tabular}

Source: Worldometer, (2020)

examine enough variables, namely dew/frost point, temperature, disaggregate temperature, wind speed, relative humidity, precipitation, and surface pressure against confirmed cases, deaths and recovery cases, spread over a period from January to April 2020 for the top 20 most infected countries. As an extension to this article mentioned above by Sarkodie and Owusu (2020), this study considers all the variables that affect Covid-19 spread across the top ten most infected countries for a period much beyond April 2020. Second, this study focuses on the top ten most affected countries, with an intent to draw much more focused results with few countries under review. The third contribution is using advanced, reliable, and accurate econometric methodologies (Dogan and Aslan 2017; Dogan et al. 2017), making it more rigorous and extensive compared to the previously published studies by employing the novel DCCE approach (Chudik and Pesaran 2015). Despite their popularity, the literature has not used these methodologies to investigate the effect of the variables on the transmission of Covid- 19 . The advanced econometric methodologies include Panel data analysis through the cross-sectional dependence test, first-generation unit root test and second-generation unit root test, Westerlund cointegration test, Dumitrescu and Hurlin's (2012) Granger non-causality test, dynamic ordinary least squares (DOLS), fully modified ordinary least squares (FMOLS), canonical cointegrating regression (CCR), augment mean group (AMG) estimations, and the novel dynamic common correlated effect (DCCE) technique.

The rest of the paper is structured as follows. The "Literature review" section presents the review of literature; the "Methodology" section presents the methodology adopted for the study; the "Findings and discussion" section presents the findings and discussions, and the "Conclusions" section concludes the paper. 


\section{Literature review}

The most frequently studied relationship of Covid-19 is related to meteorological factors and air pollutants as it influences coronavirus transmission, contributing to the spread of Covid19 (Hazbavi et al. 2020; Islam et al. 2020). The majority of the studies relate temperature with Covid-19 cases and deaths (Covid-19 indicators) and have mixed conclusions with positive/negative or no association between them. Besides temperature, a large number of meteorological factors and weather parameters are included in the study, such as absolute/relative humidity, precipitation, dew point, pressure, air quality index, wind speed and direction, solar radiation, air pollutants, and population density (Table 2).

As the spread of Covid-19 originated from Wuhan, China, in November 2019 (Iqbal et al. 2020), since then, several empirical research investigated China (/Chinese provinces), followed by the USA (Adhikari and Yin 2020; Berman and Ebisu 2020; Zangari et al. 2020), Brazil (Rosario et al. 2020; Prata et al. 2020; Auler et al. 2020), and India (Jain and Sharma 2020; Kumar 2020; Sharma et al. 2020d). USA, Brazil, and India have been in the top 3 most affected countries by Covid-19. Al-Rousan and Al-Najjar (2020) and Lin et al. (2020) study the relationship of meteorological factors and Covid-19 in China and have similar observations of the positive association of temperature and pressure with Covid19 cases. On the contrary, Liu et al. (2020), Ma et al. (2020), and Mandal et al. (2020) found negative correlations between temperature, humidity, and Covid-19 in China. Adhikari and Yin (2020) and Chien and Chen (2020) conduct their study in the USA and found a significant positive link between temperature, humidity, precipitation, and Covid-19 cases. Few studies reported the decline in the level of air pollutants (PM2.5 in all cases) during the Covid-19 period (Berman and Ebisu 2020; Jain and Sharma 2020; Sharma et al. 2020d). Ma et al. (2020) and Wu et al. (2020a, b) confirm the significant linkage of temperature and humidity with Covid-19 deaths. Rosario et al. (2020) exhibit that the increase in wind speed leads to proliferated Covid-19 cases, and Zhu et al. $(2020 \mathrm{a}, \mathrm{b})$ found that it is not closely related to incubative cases, whereas Zoran et al. (2020) establish an inverse relationship between wind speed and Covid-19 cases.

The rapid increase in the number of Covid-19 affected patients started in January 2020 and was declared a pandemic in March 2020 (WHO 2020). Since then, there is significant research happening worldwide concerning causes, consequences, transmission, etc., of Covid-19. With reference to the time frame, the period covered in most of the studies pertains either to January-February/March 2020 or FebruaryMarch/April 2020 or March-April 2020. Very few studies cover the period from January-April 2020 (Zoran et al. 2020; Gupta et al. 2020) or some days of May 2020 (Pani et al. 2020; Zhu et al. 2020a). Studies carried out in this field rely upon various methodologies and techniques to examine the relation between Covid-19 and meteorological factors, depending on country/region and the period covered.

Several statistical and scientific models are employed to examine the relations among Covid-19, meteorological factors, and air pollutants, for instance, the generalized additive model (GAM) (Xie and Zhu 2020; Zhu et al. 2020b; Liu et al. 2020), M-SEIR model (Shi et al. 2020), and AERMOD (Sharma et al. 2020d). Spearman's correlation test (MéndezArriaga 2020; Pani et al. 2020; Tosepu et al. 2020) is frequently used to correlate the Covid-19 spread and meteorological indicators. Other analysis techniques included the Wilcoxon test (Sethwala et al. 2020), $t$-tests (Berman and Ebisu 2020; Jain and Sharma 2020), spatial analysis (Zoran et al. 2020; Briz-Redón and Serrano-Aroca 2020), quantile-on-quantile approach (Shahzad et al. 2020), and wavelet approach (Fareed et al. 2020; Iqbal et al. 2020; Habib et al. 2020). Shi et al. (2020) use the M-SEIR model to explain no significant association between humidity and Covid-19. Iqbal et al. (2020) follow the Wavelet technique to find temperature does not necessarily affect Covid-19 cases.

Existing literature does not present any conclusive results about the association of temperature, wind speed, and humidity with Covid-19. There is a lack of studies examining meteorological factors, including air pressure. Till recently, no paper has been published with the data beyond May 2020 and employing panel data estimation. The present study fills this gap by using panel data analysis to examine the nexus between the Covid-19 (confirmed cases and deaths), meteorological factors (air pressure, humidity, temperature, and wind speed) including an air pollutant (PM2.5) in the world's top 10 infected countries.

\section{Methodology}

\section{Model specification and data}

This study examines the nexus between the Covid-19 confirmed cases, deaths, and meteorological factors, including an air pollutant in the world's top 10 infected countries, which include Brazil, Chile, India, Iran, Italy, Peru, Russia, Spain, UK, and USA (as on 30 June 2020, as per (CNA 2020)). The secondary data is retrieved to apply panel data estimations (that account for the heterogeneity across the nations and provide more reliable and generalizable results) from 1 February 2020 to 30 June 2020. This data relates to Covid-19 confirmed cases and deaths (Worldometer 2020); meteorological factors included in this study are daily air temperature, relative humidity, air pressure and wind speed, and air pollutant PM2.5 (WAQI 2020). We employed Panel data regression over cross-section and time-series data, being a better-modeled technique in handling all the available evidence, which cannot 


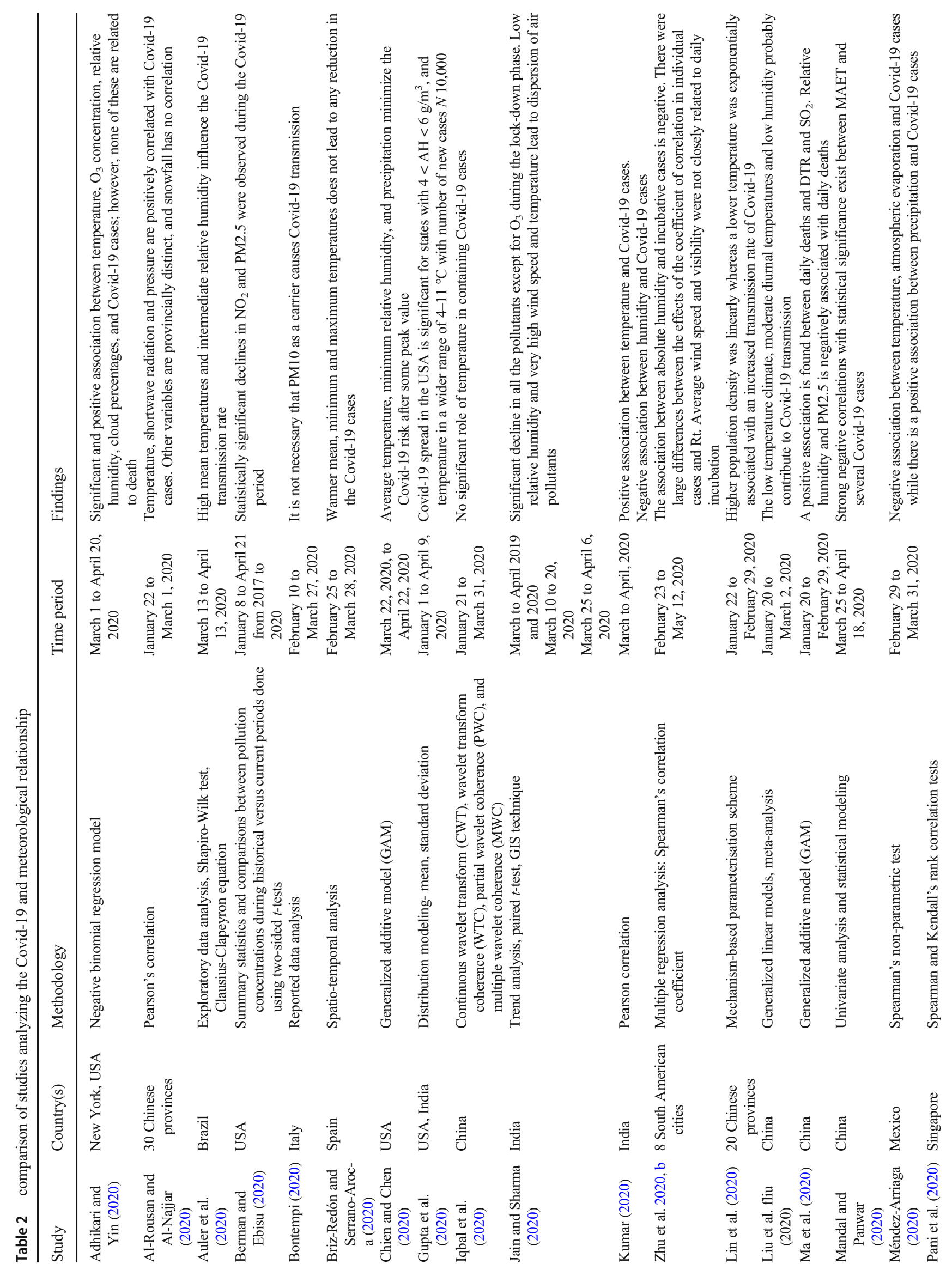


be measured in pure cross-section and time-series (Wooldridge 2002). The balanced panel data of 10 countries covering 5 months (the most prolonged period for which data is available) includes two Covid-19-related variables, four meteorological variables, and one air pollutant.

The outbreak of Covid-19 has overgrown, and mortality estimates are also rising. Hence, the study examines the nexus by proposing two models - one, with Covid-19 confirmed cases (as a dependent variable); and two, with Covid-19 death cases (as a dependent variable), with simple functions equated as follows:

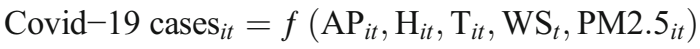

Covid-19 deaths ${ }_{i t}$

$$
=f\left(\mathrm{AP}_{i t}, \mathrm{H}_{i t}, \mathrm{~T}_{i t}, \mathrm{WS}_{t}, \mathrm{PM} 2.5_{i t}, \text { Covid-19 } \text { cases }_{i t}\right)
$$

where the subscripts $i$ and $t$ denote country and time period, respectively. Here, Covid-19 cases and deaths are the daily number of cases and deaths recorded; AP is the daily air pressure (measured in $\mathrm{hPa}$ ); $\mathrm{H}$ is the daily relative humidity (measured in \%); $\mathrm{T}$ is the daily average air temperature (measured in Celsius); WS is the daily wind speed (measured in $\mathrm{m} / \mathrm{s}$ ), and PM2.5 is the daily particulate matter 2.5 (measured in $\mu \mathrm{g} / \mathrm{m}^{3}$ ).

Equation (1) can be parameterized as follows:

Covid cases $_{\text {it }}=\mathrm{AP}_{\mathrm{it}}^{\beta 1 \mathrm{i}} H_{\mathrm{it}}^{\beta 2 \mathrm{i}} T_{\mathrm{it}}^{\beta 3 \mathrm{i}} W S_{\mathrm{it}}^{\beta 4 \mathrm{i}} P M 2.5_{\mathrm{it}}^{\beta 5 \mathrm{i}}$

Covid deaths $\mathrm{it}_{\mathrm{it}}$

$$
=\mathrm{AP}_{\mathrm{it}}^{\beta 1 \mathrm{i}} H_{\mathrm{it}}^{\beta 2 \mathrm{i}} T_{\mathrm{it}}^{\beta 3 \mathrm{i}} W S_{\mathrm{it}}^{\beta 4 \mathrm{i}} P M 2.5_{\mathrm{it}}^{\beta 5 \mathrm{i}} \text { Covid } \operatorname{cases}_{i t}^{\beta 6 \mathrm{i}}
$$

\section{Data analysis and techniques}

The data analysis begins with descriptive statistics to study the basic characteristics of the variables in the study. The study then employs econometric techniques including the crosssectional dependence test, first-generation unit root test, second-generation unit root test, Westerlund cointegration test, Dumitrescu and Hurlin's (2012) Granger non-causality test, DOLS, FMOLS, CCR, and AMG estimations.

\section{Cross-sectional dependence test}

The interconnections between global economies can lead to cross-sectional interdependence between studied countries. The CSD test, consistent with Breusch and Pagan (1980) and Pesaran (2007), resolves this methodological problem as shown in Eq. (5).

$$
\mathrm{CSD}=\sqrt{\frac{2 t}{z\left(z^{-1}\right)}}\left(\sum_{i=0}^{z^{-1}} \sum_{j=i+1}^{z^{-1}} \rho i j\right)
$$

where CSD is cross-sectional dependence, $z$ is cross-sections in the panel data, $t$ is time horizon, and pij is cross-section correlation of error between $i$ and $j$. Hence, the LM test to study the CSD test in the data series is equated as follows:

$y_{i t}=\alpha_{i t}+\beta_{i} x_{i t}+\varepsilon_{i t}$

where $t$ is time horizon and $i$ is the cross-section in the panel. The null hypothesis for both the methods states that there exists cross-sectional independence among the variables under study.

\section{First- and second-generation unit root test}

Following the estimation of cross-sectional dependency, we proceed with second-generation unit root tests, i.e., crosssectional augmented Im, Pesaran and Shin IPS (CIPS) test (test for each cross-section unit), and cross-sectionally augmented Dickey-Fuller (CADF) unit root test (to provide statistics for the variables individually). Since there exists high cross-sectional dependence in the dataset, the standard panel unit root test could not be applied. The null hypothesis for this method is that the series under study are non-stationary. The unit root test is depicted in Eq. (7) using Pesaran (2007):

$x_{t}=\alpha_{i t}+\beta_{i} x_{i t-1}+\rho_{i} t+\sum_{j=1}^{n} \theta_{i j} \Delta x_{i, t-j}+\varepsilon_{i t}$

where $\alpha_{i t}$ is intercept, $t$ is time horizon, $\Delta$ is the difference operator, $x_{i t}$ are variables under study, and $\varepsilon_{i t}$ is error term.

\section{Westerlund cointegration test}

The Westerlund (2007) cointegration test is further employed to ascertain the long-term linkage among the variables. This test assumes the existence of cross-sectional independence. Since Banerjee et al. (1998) allow for a large degree of heterogeneity among the variables, Westerlund (2007) is employed as an extension to the model and proposed four cointegration tests. The null hypothesis states that the longterm relationship does not exist between the variables. The test is applied as per the below Eq. (8):

$$
\begin{aligned}
\Delta Y_{i t}= & \delta_{i} d_{t}+\alpha_{i} Y_{i t-1}+\lambda_{i}^{\prime} X_{i, t-1}+\sum_{j=1}^{p i} \alpha_{i j} \Delta Y_{i, t-j} \\
& +\sum_{j=-q i}^{p i} Y_{i j} \Delta X_{i, t-j}+\varepsilon_{i t}
\end{aligned}
$$

where $d$ is model residuals, $i$ is cross-section in the panel data, and $t$ is time horizon.

\section{Granger non-causality test}

The direction of causality is determined using Dumitrescu and Hurlin's (2012) Granger non-causality test with the bootstrap procedure. The null hypothesis states that causality between 
the selected variables does not exist. Dumitrescu and Hurlin (2012) proposed the following regression Eq. (9):

$y_{i t}=\alpha_{i}+\sum_{k=1}^{K} \beta_{i k} y_{i, t-k}+\sum_{K=1}^{K} \gamma_{i k} x_{i, t-k}+\varepsilon_{i t}$

This equation assumes that the lag order of $K$ is the same for all individuals and that the panel must be balanced.

\section{Long-run estimation approach}

The FMOLS and DOLS models are tested to get a fully efficient estimation; (Wang and $\mathrm{Wu}$ 2012). The presence of serial correlation, if any, in the model is checked using FMOLS and DOLS. CCR exhibits lesser bias than FMOLS and DOLS and is considered better than them (Montalvo 1995). These cointegration regression tests indicate the impact of all the variables on Covid-19 confirmed cases and death cases as the dependent variables, separately.

\section{Mean group estimate}

Following the presence of cointegration, we have applied the first-generation estimators for the panel time-series-augmented mean group estimation. The mean group estimator proposed by Pesaran and Smith (1995) does not consider the cross-sectional dependence among the variables and includes a regression for each panel unit (Musaad et al. 2017). Eberhardt and Teal (2010) introduced an augmented mean group with a long-run cointegrating estimator considering heterogeneity and cross-sectional dependence (Bayar 2016). The individual regression is as follows:

$y_{i t}=\beta_{i} x_{i t}+\delta_{x i} \overline{x_{t}}+\delta_{y i} \bar{y}_{t}+e_{i t}$

where $\overline{x_{t}}=Z^{-1} \sum_{1}^{Z} x_{t}$ is the cross-sectional average of the regressors and $\overline{y_{t}}=Z^{-1} \sum_{1}^{Z} y_{t}$ is the cross-sectional average of the dependent variable.

\section{Dynamic common correlated effect model}

The literature review highlights that the previous researchers have not considered much of the cross-sectional effects and have majorly worked with homogeneous slopes (Meo et al. 2020). Hence, the panel data estimations with heterogeneous coefficients among cross-sectional units over longer periods have attracted researchers' attention in the recent past (Pesaran and Smith 1995). In this work, we have applied the dynamic common correlated effect (DCCE) approach introduced by Chudik and Pesaran (2015) to explore the variables' longterm affiliations. The DCCE model considers cross-sectional dependence and heterogeneity, providing accurate results (Meo et al. 2020). It takes cross-sectional averages and lags the response variable on the model's right side with explanatory variables. It also helps resolve variabilities (dynamics) by integrating lag-dependent variables into the model (Mensah et al. 2020). Moreover, this technique works well for the small sample size by using the jack-knife correction approach (Chudik and Pesaran 2015). We use the following the equation of the DCCE model as proposed by Chudik and Pesaran (2015):

$$
\begin{aligned}
y_{i t}= & \alpha_{i} y_{i t-1}+\delta_{i} x_{i t}+\sum_{P=0}^{P_{T}} \gamma_{x i p} \bar{X}_{t-p}+\sum_{P=0}^{P_{T}} \gamma_{y i p} \bar{Y}_{t-p} \\
& +\mu_{i t}
\end{aligned}
$$

$\delta_{\mathrm{i}} \mathrm{x}_{\mathrm{it}}$ refers to the set of independent variables, and $\mathrm{P}_{\mathrm{T}}$ is the limit of lags included in the cross-section averages.

\section{Findings and discussion}

This section begins with Table 3, presenting the ten most infected countries' descriptive statistics under study. The Covid-19 confirmed cases are, on average, about 4232 with a maximum number of cases at 54,771 , while the total number of deaths is approximately 225 with a maximum number of deaths of 4928. Among the meteorological factors, the highest variation is observed in the air pollutant PM2.5 at 40.673, followed by air pressure at a variation of 34.001. In contrast, the lowest variation is evident in the wind speed at 3.911 for all the ten countries under study. Additionally, out of all the variables, humidity, air pressure, and temperature are negatively skewed. The values for humidity and temperature are the closest to the kurtosis statistical value for normal distribution, i.e., 3. In contrast, the highest deviation from the standard statistical figure is evident in the case of air pressure, followed by wind speed and Covid-19 death cases.

Table 4 presents the cross-sectional dependence for all the variables under study. The statistical values as per the Breusch-Pagan LM test conducted over the raw values of Covid-19 cases, deaths, and all the meteorological factors are significant at $1 \%$. The logged values for PM2.5 and wind speed exhibit significance at $10 \%$, and the temperature does not reveal any significant value. According to the Pesaran scaled LM test, all the variables indicate statistical values at $1 \%$ level of significance except for the logged values of PM2.5 and temperature that do not exhibit any significant value. Furthermore, as per the Pesaran $\mathrm{CD}$ test, the raw values of all the variables excluding PM2.5 (no significant value) and humidity (statistically significant at 5\% level) exhibit a statistically significant value at $1 \%$ level. The logged values for PM2.5, humidity, temperature, and wind speed do not exhibit any significant value under the Pesaran CD test. Hence, collectively, all the study variables indicate statistically significant values confirming a strong cross-sectional dependence for the ten countries under study. 
Table 3 Descriptive statistics

\begin{tabular}{llllllll}
\hline Variables & Daily cases & Daily deaths & Humidity & PM2.5 & Pressure & Temperature & $\begin{array}{c}\text { Wind } \\
\text { speed }\end{array}$ \\
\hline Mean & 4232.096 & 225.381 & 62.744 & 59.167 & 1003.370 & 16.609 & 4.412 \\
Median & 1176.500 & 53.000 & 64.650 & 50.250 & 1011.550 & 17.158 & 3.650 \\
Maximum & 54771.000 & 4928.000 & 116.400 & 406.500 & 1032.000 & 38.500 & 77.150 \\
Minimum & 0.000 & 0.000 & 7.500 & 2.583 & 2.800 & -9.850 & 0.700 \\
Std. Dev. & 7468.903 & 425.095 & 16.212 & 40.673 & 34.001 & 7.760 & 3.911 \\
Skewness & 2.683 & 3.619 & -0.751 & 1.898 & -17.926 & -0.081 & 10.025 \\
Kurtosis & 10.490 & 23.201 & 3.668 & 10.161 & 515.228 & 2.809 & 162.292 \\
\hline
\end{tabular}

Source: authors' computation

Table 5 presents the first and second-generation unit root test for all the variables under study. All the variables under study report stationarity under both IPS and ADF-Fisher's test (first-generation unit root tests) with statistical values at $1 \%$ level of significance. All the meteorological factors show statistically remarkable values under both CIPS and CADF tests, with a $1 \%$ level of significance. According to the CIPS values, Covid-19 cases and deaths exhibit statistically significant values at the level of $1 \%$ at the first difference, while only Covid-19 death cases represent statistically significant value (at 5\%) computed at level. Hence, the degree of significance improves for both the Covid-19 cases and deaths, but the opposite is not true in case of CADF test. Alternatively, as per the CADF test, the values computed at the level for both the Covid-19 confirmed cases and death cases exhibit statistical values at $1 \%$ level of significance, while only Covid-19 cases exhibit a statistically significant value at $10 \%$ level. Therefore, for all the variables under study, an acceptable level of stationarity is observed, further validating the Westerlund cointegration test.

After the confirmation of the time-series data to be stationary as discussed above, Table 6 explains the Westerlund cointegration test (Westerlund 2007). All the four statistics, namely $G_{\mathrm{t}}, G_{\mathrm{a}}, P_{\mathrm{a}}$, and $P_{\mathrm{t}}$ reject the null hypothesis at $1 \%$ level of significance for both the Covid-19 confirmed cases and deaths. Hence, it is evident that the parameters of both the models indicate that the variables are cointegrated, confirming a long-term relationship between the variables.

Table 7 discusses the Dumitrescu and Hurlin (2012) Granger non-causality test with Covid-19 cases and Covid19 deaths as the dependent variables. Almost all the variables present statistically significant values at $1 \%$ level, with the Covid-19 cases taken as the dependent variable. The results show that bi-directional causalities exist between all the meteorological variables (including the air pollutant PM2.5) and Covid-19 cases, meaning all the variables under study drive
Table 4 Cross-sectional dependence test

\begin{tabular}{|c|c|c|c|c|}
\hline Variables & & Breusch-Pagan LM & Pesaran scaled LM & Pesaran CD \\
\hline \multirow[t]{2}{*}{ Covid-19 cases } & Raw values & $1728.8690 * * *$ & $176.4413 * * *$ & $25.6565 * * *$ \\
\hline & Logged values & $165.7510 * * *$ & $11.6741 * * *$ & $4.9356^{* * *}$ \\
\hline \multirow[t]{2}{*}{ Covid-19 deaths } & Raw values & $1448.2000 * * *$ & $146.8562 * * *$ & $21.3314 * * *$ \\
\hline & Logged values & $176.4184 * * *$ & $12.7986 * * *$ & $7.1736^{* * *}$ \\
\hline \multirow[t]{2}{*}{ Air pressure } & Raw values & $407.4721 * * *$ & $37.1538 * * *$ & $5.2383 * * *$ \\
\hline & Logged values & $186.0810 * * *$ & $13.8171 * * *$ & $4.6957 * * *$ \\
\hline \multirow[t]{2}{*}{ Humidity } & Raw values & $356.5339 * * *$ & $31.7844 * * *$ & $2.3924 * *$ \\
\hline & Logged values & $82.12862 * * *$ & $2.8596^{* * *}$ & 0.2379 \\
\hline \multirow[t]{2}{*}{ PM2.5 } & Raw values & $203.8496^{* * *}$ & $15.6901 * * *$ & -0.3173 \\
\hline & Logged values & $57.9755^{*}$ & 0.3136 & 0.4543 \\
\hline \multirow[t]{2}{*}{ Temperature } & Raw values & $3477.7480 * * *$ & $360.7893 * * *$ & $4.1820^{* * *}$ \\
\hline & Logged values & 54.0055 & -0.1048 & -0.1804 \\
\hline \multirow[t]{2}{*}{ Wind speed } & Raw values & $103.0492 * * *$ & $5.0648 * * *$ & $2.9774 * * *$ \\
\hline & Logged values & $58.3650^{*}$ & $0.3547 * * *$ & 1.2354 \\
\hline
\end{tabular}

Source: authors' computation

$*$, **, and $* * *$ denote statistical significance at $10 \%, 5 \%$, and $1 \%$ levels, respectively 
Table 5 Panel unit root test

\begin{tabular}{|c|c|c|c|c|}
\hline Variables & IPS & ADF-Fisher & CIPS & CADF \\
\hline Covid-19 cases & $-9.318 * * *$ & $135.168 * * *$ & $-1.825(-2.812)^{* * *}$ & $-5.279 * * *(-1.501) *$ \\
\hline Covid-19 deaths & $-14.406 * * *$ & $230.317 * * *$ & $-1.645 * *(-3.641)^{* * *}$ & $-1.501 *(-6.504)^{* * *}$ \\
\hline Air pressure & $-22.334 * * *$ & $446.182 * * *$ & $-4.263 * * *(-4.379) * * *$ & $-4.347 * * *(-4.519) * * *$ \\
\hline Humidity & $-23.429 * * *$ & $474.630^{* * *}$ & $-5.456 * * *(-5.106) * * *$ & $-5.462 * * *(-5.167) * * *$ \\
\hline PM2.5 & $-24.011^{* * *}$ & $489.745^{* * *} *$ & $-5.886 * * *(-5.289) * * *$ & $-6.054 * * *(-6.045) * * *$ \\
\hline Temperature & $-22.269 * * *$ & $429.840 * * *$ & $-4.433 * * *(-4.606) * * *$ & $-4.365 * * *(-4.595) * * *$ \\
\hline Wind speed & $-22.981 * * *$ & $461.491 * * *$ & $-5.126 * * *(-5.434)^{* * *}$ & $-5.122 * * *(-4.951) * * *$ \\
\hline
\end{tabular}

Source: authors' computation

$*$, **, and $* * *$ denote statistical significance at $10 \%, 5 \%$, and $1 \%$ levels, respectively

Parentheses denote $\triangle \mathrm{CIPS}$ or $\triangle \mathrm{CADF}$, i.e., at first-level difference

Covid-19 cases vice-versa. Alternatively, with Covid-19 deaths as the dependent variable, Covid-19 confirmed cases, air pressure, humidity, and temperature exhibit statistically prominent values at $1 \%$ level of significance, exhibiting bidirectional causalities with deaths. A unidirectional causality is observed from Covid-19 deaths to PM2.5 towards, and no causal relationship between deaths and wind speed. Our findings are consistent with Sarkodie and Owusu (2020), confirming the strong evidence of causality from confirmed cases to deaths and meteorological factors are good predictors of Covid-19 confirmed and death cases.

With the rapid outbreak globally, most of the infected countries, including India, implemented a country-wide lock-down to reduce the effects of the Covid-19 pandemic and discontinue its transmission. The measures like social distancing and nation-wide lock-down leading to factory and office closures and minimal traffic on roads lead to an improvement in the air quality and climatic conditions across the nations (Shakoor et al. 2020). This improvement is also validated with the causality running from Covid-19 confirmed cases to the meteorological factors, including the air pollutants PM2.5. The findings of bi-directional causalities are confirmed from the extant literature involving empirical research (Chen et al. 2020; Mandal et al. 2020; Tobías et al. 2020; Zangari et al. 2020; Kerimray et al. 2020), which observe that

Table 6 Westerlund cointegration test

\begin{tabular}{lll}
\hline Statistic & Covid-19 cases & Covid-19 deaths \\
\hline$G_{\mathrm{t}}$ & $-4.667 * * *$ & $-12.138^{* * *}$ \\
$G_{\mathrm{a}}$ & $-5.849 * * *$ & $-14.555^{* * *}$ \\
$P_{\mathrm{t}}$ & $-3.739 * * *$ & $-11.576 * * *$ \\
$P_{\mathrm{a}}$ & $-3.855^{* * *}$ & $-14.831 * * *$ \\
\hline
\end{tabular}

Source: authors' computation

$*$, **, and $* * *$ denote statistical significance at $10 \%, 5 \%$, and $1 \%$ levels, respectively
Covid-19 spread has led to lower compositions of air pollutants and more favorable weather conditions.

Table 8 depicts the long-run output elasticities using FMOLS, DOLS, and CCR estimators, considering both the Covid-19 confirmed cases and death cases as the dependent

Table 7 Dumitrescu and Hurlin's (2012) Granger non-causality test

COVID-19 confirmed cases as the dependent variable

\begin{tabular}{|c|c|c|c|}
\hline Null hypothesis & $W$-bar & $Z$-bar & $P$ values \\
\hline $\mathrm{AP} \neq>\mathrm{CC}$ & 3.4586 & 5.4976 & 0.0000 \\
\hline $\mathrm{CC} \not>\mathrm{AP}$ & 5.6580 & 10.4156 & 0.0000 \\
\hline $\mathrm{H} \neq>\mathrm{CC}$ & 2.6860 & 3.7700 & 0.0000 \\
\hline $\mathrm{CC} \neq>\mathrm{H}$ & 2.6555 & 3.7018 & 0.0002 \\
\hline $\mathrm{PM} 2.5 \neq>\mathrm{CC}$ & 2.0112 & 2.2612 & 0.0237 \\
\hline $\mathrm{CC} \neq>\mathrm{PM} 2.5$ & 3.5575 & 5.7187 & 0.0000 \\
\hline $\mathrm{T} \neq>\mathrm{CC}$ & 8.9583 & 17.7952 & 0.0000 \\
\hline $\mathrm{CC} \neq>\mathrm{T}$ & 3.2382 & 5.0047 & 0.0000 \\
\hline $\mathrm{WS} \neq>\mathrm{CC}$ & 2.3788 & 3.0830 & 0.0020 \\
\hline $\mathrm{CC} \neq>\mathrm{WS}$ & 3.5769 & 5.7620 & 0.0000 \\
\hline \multicolumn{4}{|c|}{ COVID-19 death cases as the dependent variable } \\
\hline Null hypothesis & $W$-bar & $Z$-bar & $P$ values \\
\hline $\mathrm{CC} \neq>\mathrm{CD}$ & 21.9771 & 46.9062 & 0.0000 \\
\hline $\mathrm{CD} \neq>\mathrm{CC}$ & 12.7131 & 26.1914 & 0.0000 \\
\hline $\mathrm{AP} \neq>\mathrm{CD}$ & 2.7003 & 3.8019 & 0.0001 \\
\hline $\mathrm{CD} \neq>\mathrm{AP}$ & 4.9130 & 8.7498 & 0.0000 \\
\hline $\mathrm{H} \neq>\mathrm{CD}$ & 2.2025 & 2.6888 & 0.0072 \\
\hline $\mathrm{CD} \neq>\mathrm{H}$ & 1.9797 & 2.1908 & 0.0285 \\
\hline $\mathrm{PM} 2.5 \neq>\mathrm{CD}$ & 1.2451 & 0.5480 & 0.5837 \\
\hline $\mathrm{CD} \neq>\mathrm{PM} 2.5$ & 3.5997 & 5.8130 & 0.0000 \\
\hline $\mathrm{T} \neq>\mathrm{CD}$ & 9.4679 & 18.9347 & 0.0000 \\
\hline $\mathrm{CD} \neq>\mathrm{T}$ & 4.0616 & 6.8459 & 0.0000 \\
\hline $\mathrm{WS} \neq>\mathrm{CD}$ & 0.4930 & -1.1337 & 0.2569 \\
\hline $\mathrm{CD} \neq>\mathrm{WS}$ & 1.6253 & 1.3981 & 0.1621 \\
\hline
\end{tabular}

Source: authors' computation

The symbol $\neq>$ represents "does not homogeneously cause" 
Table 8 FMOLS, DOLS, and CCR tests

\begin{tabular}{|c|c|c|c|c|c|c|}
\hline \multicolumn{7}{|c|}{ COVID-19 confirmed cases as the dependent variable } \\
\hline \multirow[t]{2}{*}{ Variables } & \multicolumn{2}{|l|}{ FMOLS } & \multicolumn{2}{|l|}{ DOLS } & \multicolumn{2}{|l|}{ CCR } \\
\hline & Coeff & Std. Error & Coeff & Std. Error & Coeff & Std. Error \\
\hline Constant & -3813.93 & 35650.03 & 333.60 & 55014.96 & -10014.53 & 43916.55 \\
\hline Air pressure & 13.5608 & 34.6428 & 10.3953 & 53.7895 & 20.1349 & 43.1194 \\
\hline Humidity & -43.0721 & 77.6577 & -41.6560 & 95.2688 & -46.4783 & 82.9315 \\
\hline Temperature & 84.5604 & 159.0306 & 78.8716 & 178.9635 & 88.9198 & 161.7144 \\
\hline PM2.5 & $-57.8187 *$ & 29.9354 & -57.2588 & 35.9549 & $-60.7429 *$ & 32.2158 \\
\hline Wind speed & -205.7897 & 304.2316 & -419.8414 & 464.8477 & -224.1494 & 367.4614 \\
\hline \multicolumn{7}{|c|}{ COVID-19 death cases as the dependent variable } \\
\hline \multirow[t]{2}{*}{ Variables } & FMOLS & & DOLS & & CCR & \\
\hline & Coeff & Std. Error & Coeff & Std. Error & Coeff & Std. Error \\
\hline Constant & -284.7038 & 826.7618 & -659.8415 & 1270.1610 & -398.1481 & 1019.7310 \\
\hline Covid-19 cases & $0.0428 * * *$ & 0.0036 & $0.0461 * * *$ & 0.0040 & $0.0426^{* * *}$ & 0.0037 \\
\hline Air pressure & 0.4902 & 0.8033 & 0.8682 & 1.2426 & 0.6029 & 1.0007 \\
\hline Humidity & -0.5612 & 1.8013 & -0.7017 & 2.2055 & -0.5387 & 1.9319 \\
\hline Temperature & -2.2156 & 3.7034 & -3.7094 & 4.1433 & -1.9952 & 3.8094 \\
\hline PM2.5 & $-1.5480 * *$ & 0.7145 & -1.2565 & 0.8602 & $-1.6409 * *$ & 0.7721 \\
\hline Wind speed & 0.4301 & 7.0864 & -0.0466 & 10.8573 & 0.7236 & 8.5659 \\
\hline
\end{tabular}

Source: authors' computation

$*$, **, and $* * *$ denote statistical significance at $10 \%, 5 \%$, and $1 \%$ levels, respectively variables, separately. With Covid-19 confirmed cases as the dependent variable, the air pollutant, namely PM2.5 alone, exhibits a statistically significant and negative impact (at $10 \%$ level of significance) on the Covid-19 confirmed cases, as per the FMOLS and CCR statistical values.

Alternatively, with Covid-19 death cases as the dependent variable, Covid-19 confirmed cases reveal a statistically significant and positive impact (at $1 \%$ level of significance) on the Covid-19 death cases, according to all the three statistical values under FMOLS, DOLS, and CCR. Additionally, the air pollutant PM2.5 exhibits a statistically significant and negative impact (at $5 \%$ level of significance) on the Covid-19 death cases, as per the FMOLS and CCR statistical values.

Hence, air pollutant PM2.5 exhibits a significant negative impact (at $10 \%$ and $5 \%$ level of significance) on the Covid-19 confirmed cases and death cases in the concerned countries. This finding is consistent with the result by Chen et al. (2020), which states that reduction in the air pollutant serves as a resistance to the continually increasing Covid-19 death cases in China. Also, Fareed et al. (2020) and Wu, Nethery, Sabath, Braun, and Dominici (2020) reveal that exposure to air pollutant PM2.5 leads to massive deaths by Covid-19 in the USA and China, complementing our results.

Table 9 presents the augmented mean group estimates while considering the Covid-19 confirmed cases as the dependent variable. Temperature exhibits a statistically significant impact (at 1\% level) on the Covid-19 confirmed cases of all the countries except for Iran, where there is a significant impact but at a $5 \%$ level of significance.
Moreover, our results show a positive association of temperature and confirmed cases in countries like Brazil (Rosario et al. 2020), India (Kumar 2020), Iran, and Russia. In contrast, in most countries, it is inversely related, as supported by Wang et al. (2020) and Wu et al. (2020b). Furthermore, air pollutant PM2.5 and air pressure impact the Covid-19 confirmed cases in most countries under study.

All the meteorological variables, including PM2.5, have a strong statistical and significant impact on Brazil's Covid-19 confirmed cases. The finding is consistent with the results by Auler et al. (2020) and Pequeno et al. (2020) that find a positive linear relationship between the meteorological factors and cases in Brazil, while the results contradict the findings opined by Prata et al. (2020).

In the case of India, all the meteorological variables, including the air pollutant PM2.5, indicate a statistically significant impact (at $1 \%$ level of significance) on its Covid-19 confirmed cases. This study serves as an extension to the research by Gupta et al. (2020), which finds no correlation between the vulnerable weather conditions and Covid-19 new cases in India, considering its limited study timeline, while this study includes a more extended timeline. The findings also contradict the results by Kumar (2020), which opine that the cases shall diminish in warmer, humid, and during summer/monsoon regions, as proven by the rising number of cases in India.

Chile reports temperature and wind speed to be statistically significant (at 1\% level) and exhibit a negative and a positive impact on its confirmed cases, respectively. Humidity, PM2.5, 
Table 9 Augmented mean group (COVID-19 confirmed cases as the dependent variable)

\begin{tabular}{|c|c|c|c|c|c|c|}
\hline Countries/variables & Constant & Air pressure & Humidity & PM2.5 & Temperature & Wind speed \\
\hline Overall & 34620.77 & -35.6179 & 12.2519 & -6.8876 & -97.2345 & -28.9052 \\
\hline Brazil & $-630951.40 * *$ & $625.0123 * *$ & $156.0854 * * *$ & $377.2397 * * *$ & $652.9533 * * *$ & $2855.2790 * * *$ \\
\hline Chile & -27124.40 & 25.1506 & -8.0566 & 7.0845 & $-303.7789 * * *$ & $1777.0260 * * *$ \\
\hline India & $95356.34 * * *$ & $-110.5546^{* * *}$ & $128.8052 * * *$ & $17.4921 * * *$ & $238.5444 * * *$ & $-387.8335^{* * *}$ \\
\hline Iran & 6003.82 & -5.7759 & $11.9933 * *$ & $-4.71432 * * *$ & $37.9936 * *$ & -14.17705 \\
\hline Italy & $127826.00^{* * *}$ & $-121.9681 * * *$ & -12.1677 & $36.2624 * * *$ & $-246.0241 * * *$ & $-134.9306^{* * *}$ \\
\hline Peru & $-253809.80^{* * *}$ & $265.7233 * * *$ & $-52.0348 * *$ & 0.3423 & $-440.5213 * * *$ & -11.9321 \\
\hline Russia & $63184.86 * * *$ & $-60.9156^{* * *}$ & -8.0054 & $-42.1488 * * *$ & $212.4598 * * *$ & 41.2581 \\
\hline Spain & $49911.29 * * *$ & $-45.4864 * * *$ & 18.0563 & $-23.6618 * * *$ & $-181.8085^{* * *}$ & -78.1316 \\
\hline UK & -7364.99 & 12.8288 & $-62.5167 * * *$ & -0.6704 & $-123.8335 * * *$ & $349.5079 * * *$ \\
\hline USA & 7501.69 & -3.0417 & 61.6737 & -66.2375 & $-641.5810 * * *$ & 22.7662 \\
\hline
\end{tabular}

Source: authors' computation

$*, * *$, and $* * *$ denote statistical significance at $10 \%, 5 \%$, and $1 \%$ levels, respectively

and temperature reveal a significant impact on the cases in Iran, which is partially consistent with the findings by Ahmadi et al. (2020) that prove humidity, wind speed, and solar radiation exposure support the transmission of coronavirus in Iran. Additionally, the results contradict the findings opined by Jahangiri et al. (2020), finding a low correlation between the cases and ambient temperature in Iran.

Except for humidity, all the meteorological factors confirm a statistically significant impact on the Covid-19 confirmed cases in Italy. The findings contradict the results proven by Bontempi (2020) who find no relationship between the particulate matter and the rising Covid-19 cases, while the same is consistent with the results opined by Zoran et al. (2020) who find a significant impact of climatic variables and the cases in Italy. A strong positive association of the concentration of PM2.5 with cases is found in Italy (Lippi et al. 2020).

Alternatively, the findings conclude that air pressure, humidity, and temperature significantly affect the cases in Peru. Air pressure, PM2.5, and temperature have a statistically significant impact (at $1 \%$ level of significance) on the rising cases in Russia and Spain (contradicting the result by Briz-Redón and Serrano-Aroca (2020) and Shahzad et al. (2020) which prove no relation between temperature and Covid-19 cases in Spain). The UK exhibits a statistically significant impact by humidity, temperature, and wind speed on its confirmed cases. The former finding is consistent with the results proven by Travaglio, Popovic, Yu, Leal, and Martins (2020) who find low air quality to be associated with the rising Covid-19 cases in England.

The findings report that temperature has a significant negative impact at $1 \%$ level of significance on the Covid19 confirmed cases in the USA, which is also consistent with the findings by Bashir et al. (2020), who opine that average temperature, minimum temperature, and air quality to be significantly associated with the Covid-19 pandemic in the USA.

Table 10 presents the augmented mean group estimates while considering the Covid-19 death cases as the dependent variable. Covid-19 confirmed cases exhibit a statistically significant (at $1 \%$ level of significance) and positive impact on the Covid-19 death cases across all the ten countries under study, with the highest impact evident in Italy, where the confirmed cases impact the death cases by 0.1123 units. Out of all the meteorological variables, temperature exhibits a significant negative impact on the death cases in most countries (Wu et al. 2020b) under study, followed by air pressure and humidity (Ma et al. 2020). This finding is consistent with the results by Ma et al. (2020), where the author confirms temperature and humidity as important factors affecting Covid-19 mortality in China.

Countries, namely, India, Spain, and the USA, reveal only temperature and Covid-19 cases to be the essential factors affecting the number of death cases in these countries. This finding contradicts the results by Adhikari and Yin (2020), which confirms no impact by any of the meteorological factors on the death cases in New York, USA, while Brazil and Iran reveal air pressure, in addition to temperature and Covid-19 confirmed cases, to impact its death cases. Similarly, Chile shows wind speed as an essential variable that negatively affects the death cases in the country by 18.45 units. Furthermore, humidity in Italy and Peru has a negative impact on the Covid-19 death cases, as consistent with the results by Fareed et al. (2020). Additionally, UK reveals only air pressure and confirmed cases to have a negative and positive impact on its death cases, respectively. Lastly, Russia exhibits a positive impact of air pressure, humidity, temperature, and Covid-19 confirmed cases, concluding it to be the only country where most of the variables under study impact its death cases. 
Table 10 Augmented mean group (COVID-19 death cases as the dependent variable)

\begin{tabular}{|c|c|c|c|c|c|c|c|}
\hline Countries/variables & Constant & Air pressure & Humidity & PM2.5 & Temperature & Wind speed & Covid-19 cases \\
\hline Overall & 529.25 & -0.4343 & -0.1614 & 0.0657 & $-4.5765^{*}$ & -0.4067 & $0.0364 * * *$ \\
\hline Brazil & $-15320.32 * *$ & $16.5607 * *$ & 1.2267 & 0.4780 & $-13.6685 * * *$ & -41.8146 & $0.0318 * * *$ \\
\hline Chile & 84.57 & 0.0469 & 0.4234 & 0.1155 & $-3.7739^{*}$ & $-18.4571 * * *$ & $0.0078 * * *$ \\
\hline India & 2784.17 & -2.4807 & -0.7962 & -0.1660 & $-10.4452 *$ & -3.7573 & $0.0382 * * *$ \\
\hline Iran & $931.21 *$ & $-0.9071^{*}$ & 0.4154 & 0.0796 & $-1.2489 * *$ & -0.9300 & $0.0407 * * *$ \\
\hline Italy & 1743.83 & -1.5856 & $-1.5063 * *$ & 0.0215 & $-3.3447 * *$ & -0.3098 & $0.1123 * * *$ \\
\hline Peru & -2035.72 & 2.6181 & $-2.0947 * * *$ & 0.0830 & $-18.3167 * * *$ & -1.0065 & $0.0108 * * *$ \\
\hline Russia & $-728.15 * *$ & $0.6663 * *$ & $0.6031 * *$ & 0.2640 & $2.4595 * * *$ & 0.5017 & $0.0105 * * *$ \\
\hline Spain & -379.56 & 0.3680 & 0.4440 & -0.0644 & $-5.2776 * *$ & 2.9427 & $0.0773 * * *$ \\
\hline UK & $2200.93 * * *$ & $-2.2574 * * *$ & -0.0176 & -0.1435 & 3.8124 & -0.7229 & $0.0516^{* * *}$ \\
\hline USA & 124.51 & -0.0409 & -3.9137 & 3.9048 & -0.3409 & 0.0482 & $0.0103 * * *$ \\
\hline
\end{tabular}

Source: authors' computation

$*$, **, and $* * *$ denote statistical significance at $10 \%, 5 \%$, and $1 \%$ levels, respectively

Considering the issue of endogeneity and cross-sectional dependence (confirmed from the CD test), the study further employs the DCCE model. Table 11 presents the results of the DCCE model. The first part of Table 11 shows the results with Covid-19 confirmed cases as the dependent variable. Consistent with the results proven by the augmented mean group estimation technique, all the variables (except for humidity and wind speed) report a significant impact on the Covid-19 confirmed cases. Overall, temperature and air pressure exhibit a significant but negative impact, implying

Table 11 Dynamic common correlated effect (DCCE) estimation

COVID-19 confirmed cases as the dependent variable

\begin{tabular}{lll} 
Explanatory variables & Coeff & Std. error \\
Constant & -247.83 & 198.6260 \\
Air pressure & $-3.9536^{* * *}$ & 1.2981 \\
Humidity & 0.3085 & 0.2818 \\
PM2.5 & $0.0251^{* * *}$ & 0.0021 \\
Temperature & $-0.3675^{* *}$ & 0.1721 \\
Wind speed & 0.2056 & 0.1720 \\
COVID-19 death cases as the dependent variable & \\
Explanatory variables & Coeff & Std. error \\
Constant & $-933.80^{* * *}$ & 250.0650 \\
Covid-19 cases & $0.0323^{* *}$ & 0.0141 \\
Air pressure & 1.9540 & 2.6348 \\
Humidity & 0.0343 & 0.5112 \\
PM2.5 & $0.7548^{* *}$ & 0.3782 \\
Temperature & $-5.7023^{* *}$ & 2.4512 \\
Wind speed & -2.8108 & 3.6213 \\
\hline
\end{tabular}

Source: authors' computation

$* *$ and $* * *$ denote statistical significance at $5 \%$ and $1 \%$ levels, respectively that an increase in temperature and air pressure shall decrease the number of confirmed cases. Moreover, our results indicate that there is a negative association of temperature and confirmed cases in most countries, which is also supported by Wang et al. (2020) and Wu et al. (2020b). Air pollutant PM2.5 indicates a positive and statistically significant impact, implying that an increase in their levels will ultimately lead to an increase in the number of confirmed cases. Our result is partially consistent with the results by Heneghan and Jefferson (2020), where the authors state that the climatic conditions, including temperature and air pressure have a significant impact on the transmission of the disease. Lolli et al. (2020) also find a negative correlation between temperature and virus transmission, while air pressure exhibits a certain degree of correlation. Hence, it is possible to speculate that cool and dry weather conditions with lower temperature shall contribute to the transmission of the Covid-19 pandemic.

The second part of Table 11 presents the results with Covid19 death cases as the dependent variable. Similar to the augmented mean group estimation technique, temperature and Covid-19 confirmed cases exhibit statistically significant results. The findings are aligned with $\mathrm{Wu}$ et al. (2020b), who opine that temperature is negatively associated with the daily new deaths of Covid-19 worldwide. However, unlike the previous tests, we find air pollutant PM2.5 to positively and significantly impact death cases (at 5\% level of significance). This impact of PM2.5 is further validated by Zoran et al. (2020), Magazzino et al. (2020), and Wu, Nethery, Sabath, Braun, and Dominici (2020), who conclude that air pollutant PM2.5 reports a strong positive impact on the Covid-19 death cases. Also, wind speed and humidity do not exhibit any significant impact. This finding partially contradicts the results by Ma et al. (2020) and Sobral et al. (2020), where the authors confirm the significant impact of humidity, and no impact of temperature on Covid-19 death cases, respectively. 


\section{Conclusions}

The coronavirus cases have reached up to 26 million cases and 0.8 million deaths worldwide as of 5 September 2020 (Worldometer 2020). Given the virus's novelty and the constant increase in the number of cases and deaths, it is imperative to look for the causes behind this widespread pandemic. While there has been progress in managing this disease, the factors apart from age, which affect the severity and mortality of this pandemic, are still not clear (Travaglio et al. 2020). Heneghan and Jefferson (2020) exert that other environmental factors, including air density, air pollution, and daily sunlight, require urgent verification and should be considered for further investigation and testing. Additionally, extant literature highlighted the possible impact of the meteorological factors but has been inconclusive about the role and the degree of influence of such factors on the Covid-19 cases (Iqbal et al. 2020; Xie and Zhu 2020). Given the climatic differences among these most affected ten countries, it seems reasonable to examine the impact of such meteorological factors, including an air pollutant for each of these countries too. This is one of the first studies that take into consideration the nexus between the confirmed Covid-19 confirmed cases, deaths, meteorological factors, including an air pollutant in the world's top 10 infected countries, from 1 February 2020 through 30 June 2020, using advanced econometric techniques (Sharma et al. 2020a; Nathaniel et al. 2020), including the novel Dynamic Common Correlated Effect (DCCE) model that accounts for the heterogeneity across the nations and provide more reliable and generalizable results (Mensah et al. 2020; Meo et al. 2020)

Our findings confirm a strong cross-sectional dependence between Covid-19 cases, deaths, and the meteorological factors, including air pollutant PM2.5, for all the ten most infected countries under study. The Westerlund (2007) cointegration test confirms a long-term relationship between all the variables under investigation. With Covid-19 cases as the dependent variable, there exists bi-directional causalities running between the Covid-19 cases and all the meteorological factors, namely temperature, wind speed, humidity, air pressure, and PM2.5 (an air pollutant). With Covid-19 death cases as the dependent variable, the bi-directional causality runs between the Covid-19 death cases, and Covid-19 confirmed cases, air pressure, humidity, and temperature. Temperature and air pressure exhibit a statistically significant and negative impact on the Covid-19 confirmed cases. Air pollutant PM2.5 also exhibits a significant but positive impact on the Covid-19 confirmed cases. Temperature indicates a statistically significant and negative impact on Covid-19 death cases. Simultaneously, Covid-19 confirmed cases and air pollutant PM2.5 exhibit a statistically significant and positive impact on the Covid-19 death cases across the ten countries under study. Hence, it is possible to postulate that cool and dry weather conditions with lower temperature and higher humidity promote indoor activities and human gatherings (assembling), leading to virus transmission.

This study contributes both practically and theoretically to the concerned field of pandemic management. The results herewith provide a better understanding and may assist in taking appropriate measures in implementing intersectoral policies and actions as necessary in a timely and efficient manner. Hence, protection and prevention measures must be adopted to reduce the transmission and possible collapse of the public health system. Such measures shall also encourage e-government initiatives, work-from-home policies for corporates and businesses, improved healthcare sector and facilities, investment in sustainable infrastructure, and better policies for the most vulnerable societies, including the migrants and the daily wage earners. In conclusion, this study provides vital information on the impact of meteorological factors, including an air pollutant, on the rising Covid-19 confirmed cases and death cases. Such information shall lead to a better understanding of the weather parameters responsible for spreading the Covid-19 virus across the most infected countries under study. Lastly, the results may also help the weather forecasting authorities better identify the regions with similar weather conditions that further support the virus's spread. The present air quality scenarios have gathered all stakeholders' attention from a scientific, academic, policy decision, and political background, emphasizing the need to identify how to handle future air quality scenarios. Additionally, the experts may rethink and reform the policy measures to reduce the overall impact on the environment and economy together, keeping the policy decisions in line with the sustainable development goals (SDGs).

The study has some limitations. The study has not considered other factors, including demographic variables, personal behaviors, healthcare infrastructure, medical resources, socioeconomic factors, and healthcare sector programs and policies (government response), regulating the transmission of the disease. Therefore, these confounding factors should also be incorporated into such models (as the ones used in this study) and as much as possible empirically tested in future studies. The dataset used for this study is very extensive, but a more extensive dataset, including varying weather conditions, should also be considered by future studies. Also, the dataset included in the study includes the data from February to June; therefore, more recent data could be added to give a more comprehensive picture of the findings.

Supplementary Information The online version contains supplementary material available at https://doi.org/10.1007/s11356-021-12668-5.

Acknowledgements The authors are grateful to Guru Gobind Singh Indraprastha University for providing funds and allowing time to conduct this research. 
Author Contribution Conceptualization: GDS, SB. Data curation: AY, IG, MJ. Formal analysis: AY, MJ. Investigation: GDS, SB. Methodology: AY, IG. Project administration: SB. Resources: GDS, SB. Software: AY, MJ. Supervision: GDS, SB. Validation: GDS, SB. Visualization: GDS, AY, MJ. Original draft: AY, IG, MJ. Review and editing: GDS. Proof-reading: GDS, SB.

Data availability The datasets used and/or analyzed during the current study are available from the corresponding author on reasonable request.

\section{Declarations}

Conflict of Interest The authors declare that they have no conflict of interest.

\section{References}

Adhikari A, Yin J (2020) Short-term effects of ambient ozone, PM2.5, and meteorological factors on COVID-19 confirmed cases and deaths in Queens, New York. Int J Environ Res Public Health 17: 1-13. https://doi.org/10.3390/ijerph17114047

Ahmadi M, Sharifi A, Dorosti S, Jafarzadeh Ghoushchi S, Ghanbari N (2020) Investigation of effective climatology parameters on COVID-19 outbreak in Iran. Sci Total Environ 729:138705. https://doi.org/10.1016/j.scitotenv.2020.138705

Al-Rousan N, Al-Najjar H (2020) The correlation between the spread of COVID-19 infections and weather variables in 30 Chinese provinces and the impact of Chinese government mitigation plans. Eur Rev Med Pharmacol Sci 24:4565-4571. doi: 10.26355/ eurrev 20200421042

Auler AC, Cássaro FAM, da Silva VO, Pires LF (2020) Evidence that high temperatures and intermediate relative humidity might favor the spread of COVID-19 in tropical climate: a case study for the most affected Brazilian cities. Sci Total Environ 729:139090. https://doi.org/10.1016/j.scitotenv.2020.139090

Banerjee A, Dolado JJ, Mestre R (1998) Error-correction mechanism tests for cointegration in a single-equation framework. J Time Ser Anal. 19:267-283. https://doi.org/10.1111/1467-9892.00091

Bashir MF, Ma B, Bilal et al (2020) Correlation between climate indicators and COVID-19 pandemic in New York, USA. Sci Total Environ 728:138835. https://doi.org/10.1016/j.scitotenv.2020. 138835

Bayar Y (2016) Financial development and unemployment in emerging market economies. Sci Ann Econ Bus 63:237-245. https://doi.org/ 10.1515/aicue-2016-0019

Berman JD, Ebisu K (2020) Changes in U.S. air pollution during the COVID-19 pandemic. Sci Total Environ 739:139864. https://doi. org/10.1016/j.scitotenv.2020.139864

Bontempi E (2020) First data analysis about possible COVID-19 virus airborne diffusion due to air particulate matter (PM): the case of Lombardy (Italy). Environ Res 186:109639. https://doi.org/10. 1016/j.envres.2020.109639

Breusch TS, Pagan AR (1980) The Lagrange multiplier test and its applications to model specification in econometrics. Rev Econ Stud 47:239. https://doi.org/10.2307/2297111

Briz-Redón Á, Serrano-Aroca Á (2020) A spatio-temporal analysis for exploring the effect of temperature on COVID-19 early evolution in Spain. Sci Total Environ 728:138811. https://doi.org/10.1016/j. scitotenv.2020.138811

Casanova LM, Jeon S, Rutala WA, Weber DJ, Sobsey MD (2010) Effects of air temperature and relative humidity on coronavirus survival on surfaces. Appl Environ Microbiol 76:2712-2717. https://doi.org/10. 1128/AEM.02291-09
Chakraborty I, Maity P (2020) COVID-19 outbreak: migration, effects on society, global environment and prevention. Sci Total Environ 728: 138882. https://doi.org/10.1016/j.scitotenv.2020.138882

Chen K, Wang M, Huang C, Kinney PL, Anastas PT (2020) Air pollution reduction and mortality benefit during the COVID-19 outbreak in China. Lancet Planet Heal 2020(03):23.20039842-23.2003e212. https://doi.org/10.1016/S2542-5196(20)30107-8

Chien LC, Chen LW (2020) Meteorological impacts on the incidence of COVID-19 in the U.S. Stoch Environ Res Risk Assess 8. https://doi. org/10.1007/s00477-020-01835-8

Chudik A, Pesaran MH (2015) Common correlated effects estimation of heterogeneous dynamic panel data models with weakly exogenous regressors. J Econom 188:393-420. https://doi.org/10.1016/j. jeconom.2015.03.007

CNA (2020) Novel Coronavirus COVID-19 - Latest news | CNA. Channel News Asia, In

Dogan E, Aslan A (2017) Exploring the relationship among CO2 emissions, real GDP, energy consumption and tourism in the EU and candidate countries: Evidence from panel models robust to heterogeneity and cross-sectional dependence. Renew Sustain Energy Rev 77:239-245. https://doi.org/10.1016/j.rser.2017.03.111

Dogan E, Seker F, Bulbul S (2017) Investigating the impacts of energy consumption, real GDP, tourism and trade on $\mathrm{CO} 2$ emissions by accounting for cross-sectional dependence: a panel study of OECD countries. Curr Issues Tour 20:1701-1719. https://doi.org/10.1080/ 13683500.2015.1119103

Dumitrescu EI, Hurlin C (2012) Testing for Granger non-causality in heterogeneous panels. Econ Model 29:1450-1460. https://oi.org/ 10.1016/j.econmod.2012.02.014

Dutheil F, Baker JS, Navel V (2020) COVID-19 and air pollution : the worst is yet to come. Environ Sci Pollut Res 27:44647-44649. https://doi.org/10.1007/s11356-020-11075-6

Eberhardt M, Teal F (2010) Productivity analysis in global manufacturing production. Econ Ser Work Pap

Fareed Z, Iqbal N, Shahzad F, Shah SGM, Zulfiqar B, Shahzad K, Hashmi SH, Shahzad U (2020) Co-variance nexus between COVID-19 mortality, humidity, and air quality index in Wuhan, China: new insights from partial and multiple wavelet coherence. Air Qual Atmos Heal 13:673-682. https://doi.org/10.1007/s11869020-00847-1

Gupta S, Raghuwanshi GS, Chanda A (2020) Effect of weather on COVID-19 spread in the US: a prediction model for India in 2020. Sci Total Environ 728:138860. https://doi.org/10.1016/j.scitotenv. 2020.138860

Habib Y, Xia E, Fareed Z, Hashmi SH (2020) Time-frequency comovement between COVID-19, crude oil prices, and atmospheric $\mathrm{CO} 2$ emissions: fresh global insights from partial and multiple coherence approach. Environ Dev Sustain:1-21. https://doi.org/10. 1007/s10668-020-01031-2

Hazbavi Z, Mostfazadeh R, Alaei N, Azizi E (2020) Spatial and temporal analysis of the COVID-19 incidence pattern in Iran. Environ Sci Pollut Res:1-11. https://doi.org/10.1007/s11356-020-11499-0

Heneghan C, Jefferson T (2020) Effect of latitude on COVID-19. In: Cent. Evidence-Based Med. https://www.cebm.net/covid-19/ effect-of-latitude-on-covid-19/. Accessed 20th November 2020

Iqbal N, Fareed Z, Shahzad F, He X, Shahzad U, Lina M (2020) The nexus between COVID-19, temperature and exchange rate in Wuhan city: new findings from partial and multiple wavelet coherence. Sci Total Environ 729:138916. https://doi.org/10.1016/j. scitotenv.2020.138916

Islam ARMT, Hasanuzzaman M, Shammi M et al (2020) Are meteorological factors enhancing COVID-19 transmission in Bangladesh? Novel findings from a compound Poisson generalized linear modeling approach. Environ Sci Pollut Res 1-14. https://doi.org/10.1007/ s11356-020-11273-2 
Jahangiri M, Jahangiri M, Najafgholipour M (2020) The sensitivity and specificity analyses of ambient temperature and population size on the transmission rate of the novel coronavirus (COVID-19) in different provinces of Iran. Sci Total Environ 728:138872. https://doi. org/10.1016/j.scitotenv.2020.138872

Jain S, Sharma T (2020) Social and travel lockdown impact considering coronavirus disease (Covid-19) on air quality in megacities of india: present benefits, future challenges and way forward. Aerosol Air Qual Res 20:1222-1236. https://doi.org/10.4209/aaqr.2020.04. 0171

Kerimray A, Baimatova N, Ibragimova OP, Bukenov B, Kenessov B, Plotitsyn P, Karaca F (2020) Assessing air quality changes in large cities during COVID-19 lockdowns: the impacts of traffic-free urban conditions in Almaty, Kazakhstan. Sci Total Environ 730: 139179. https://doi.org/10.1016/j.scitotenv.2020.139179

Kumar S (2020) Will COVID-19 pandemic diminish by summermonsoon in India? Lesson from the first lockdown. medRxiv 2020.04.22.20075499. https://doi.org/10.1101/2020.04.22. 20075499

Lee J-W, McKibbin WJ (2004) Globalization and disease: the case of SARS. Asian Econ Pap 3:113-131. doi: 10. 1162/1535351041747932

Lin C, Lau AKH, Fung JCH et al (2020) A mechanism-based parameterisation scheme to investigate the association between transmission rate of COVID-19 and meteorological factors on plains in China. Sci Total Environ 737. https://doi.org/10.1016/j.scitotenv. 2020.140348

Lippi G, Sanchis-Gomar F, Henry BM (2020) Association between environmental pollution and prevalence of coronavirus disease 2019 (COVID-19) in Italy. medRxiv 19:2020.04.22.20075986. https:// doi.org/10.1101/2020.04.22.20075986

Liu J, Zhou J, Yao J, Zhang X, Li L, Xu X, He X, Wang B, Fu S, Niu T, Yan J, Shi Y, Ren X, Niu J, Zhu W, Li S, Luo B, Zhang K (2020) Impact of meteorological factors on the COVID-19 transmission: a multi-city study in China. Sci Total Environ 726:138513. https://doi. org/10.1016/j.scitotenv.2020.138513

Lolli S, Chen YC, Wang SH, Vivone G (2020) Impact of meteorological conditions and air pollution on COVID-19 pandemic transmission in Italy. Sci Rep 10:16213. https://doi.org/10.1038/s41598-02073197-8

Ma Y, Zhao Y, Liu J, He X, Wang B, Fu S, Yan J, Niu J, Zhou J, Luo B (2020) Effects of temperature variation and humidity on the death of COVID-19 in Wuhan, China. Sci Total Environ 724:138226. https://doi.org/10.1016/j.scitotenv.2020.138226

Magazzino C, Mele M, Schneider N (2020) The relationship between air pollution and COVID-19-related deaths: an application to three French cities. EnerarXiv

Mandal CC, Panwar MS (2020) Can the summer temperatures reduce COVID-19 cases? Public Health 185:72-79. https://doi.org/10. 1016/j.puhe.2020.05.065

Mandal A, Roy R, Ghosh D, et al (2020) COVID-19 pandemic: sudden restoration in global environmental quality and its impact on climate change. EnerarXiv

Méndez-Arriaga F (2020) The temperature and regional climate effects on communitarian COVID-19 contagion in Mexico throughout phase 1. Sci Total Environ 735:139560. https://doi.org/10.1016/j. scitotenv.2020.139560

Mensah IA, Sun M, Gao C et al (2020) Investigation on key contributors of energy consumption in dynamic heterogeneous panel data (DHPD) model for African countries: fresh evidence from dynamic common correlated effect (DCCE) approach. Environ Sci Pollut Res 27:38674-38694. https://doi.org/10.1007/s11356-020-09880-0

Meo MS, Sabir SA, Arain H, Nazar R (2020) Water resources and tourism development in South Asia: an application of dynamic common correlated effect (DCCE) model. Environ Sci Pollut Res 27:1967819687. https://doi.org/10.1007/s11356-020-08361-8
Montalvo JG (1995) Comparing cointegrating regression estimators: some additional Monte Carlo results. Econ Lett. 48:229-234. https://doi.org/10.1016/0165-1765(94)00632-C

Musaad HMA, Bin ZY, Ameer W (2017) The long-run effect of FDI inflows on total factor productivity : evidence from African countries

Nakada LYK, Urban RC (2020) COVID-19 pandemic: environmental and social factors influencing the spread of SARS-CoV-2 in São Paulo. Brazil. Environ Sci Pollut Res:1-7. https://doi.org/10.1007/ s11356-020-10930-w

Nathaniel S, Nwodo O, Sharma G, Shah M (2020) Renewable energy, urbanization, and ecological footprint linkage in CIVETS. Environ Sci Pollut Res 27:19616-19629. https://doi.org/10.1007/s11356020-08466-0

Pani SK, Lin NH, Babu SR (2020) Association of COVID-19 pandemic with meteorological parameters over Singapore. Sci Total Environ 740:140112. https://doi.org/10.1016/j.scitotenv.2020.140112

Pequeno P, Mendel B, Rosa C, Bosholn M, Souza JL, Baccaro F, Barbosa R, Magnusson W (2020) Air transportation, population density and temperature predict the spread of COVID-19 in Brazil. PeerJ 8:e9322. https://doi.org/10.7717/peerj.9322

Pesaran MH (2007) A simple panel unit root test in the presence of crosssection dependence. J Appl Econom 22:265-312. https://doi.org/10. 1002/jae. 951

Pesaran MH, Smith R (1995) Estimating long-run relationships from dynamic heterogeneous panels

Prata DN, Rodrigues W, Bermejo PH (2020) Temperature significantly changes COVID-19 transmission in (sub)tropical cities of Brazil. Sci Total Environ 729:138862. https://doi.org/10.1016/j.scitotenv. 2020.138862

Raza A, Khan MTI, Ali Q, Hussain T, Narjis S (2020) Association between meteorological indicators and COVID-19 pandemic in Pakistan. Environ Sci Pollut Res:1-16. https://doi.org/10.1007/ s11356-020-11203-2

Rosario DKA, Mutz YS, Bernardes PC, Conte-Junior CA (2020) Relationship between COVID-19 and weather: case study in a tropical country. Int J Hyg Environ Health 229:1-5. https://doi.org/10. 1016/j.ijheh.2020.113587

Sarkodie SA, Owusu PA (2020) Impact of meteorological factors on COVID-19 pandemic: evidence from top 20 countries with confirmed cases. Environ Res 191:110101. https://doi.org/10.1016/j. envres.2020.110101

Sethwala A, Akbarally M, Better N et al (2020) The effect of ambient temperature on worldwide COVID-19 cases and deaths - an epidemiological study. Medrxiv:1-22. https://doi.org/10.1101/2020.05. 15.20102798

Shahzad F, Shahzad U, Fareed Z, Iqbal N, Hashmi SH, Ahmad F (2020) Asymmetric nexus between temperature and COVID-19 in the top ten affected provinces of China: a current application of quantile-onquantile approach. Sci Total Environ 736:139115. https://doi.org/ 10.1016/j.scitotenv.2020.139115

Shahzad K, Shahzad U, Iqbal N, Shahzad F, Fareed Z (2020) Effects of climatological parameters on the outbreak spread of COVID-19 in highly affected regions of Spain. Environ Sci Pollut Res 27:3965739666. https://doi.org/10.1007/s11356-020-10551-3

Shakoor A, Chen X, Farooq TH, Shahzad U, Ashraf F, Rehman A, Sahar N, Yan W (2020) Fluctuations in environmental pollutants and air quality during the lockdown in the USA and China: two sides of COVID-19 pandemic. Air Qual Atmos Heal 13:1335-1342. https:// doi.org/10.1007/s11869-020-00888-6

Sharma GD, Rahman MM, Jain M, Chopra R (2020a) Nexus between energy consumption, information and communications technology, and economic growth: an enquiry into emerging Asian countries. J Public Aff. https://doi.org/10.1002/pa.2172 
Sharma GD, Talan G, Jain M (2020b) Policy response to the economic challenge from COVID-19 in India : a qualitative enquiry. J Public Aff:1-16. https://doi.org/10.1002/pa.2206

Sharma GD, Talan G, Srivastava M, Yadav A, Chopra R (2020c) A qualitative enquiry into strategic and operational responses to Covid-19 challenges in South Asia. J Public Aff. https://doi.org/ 10.1002/pa.2195

Sharma S, Zhang M, Anshika et al (2020d) Effect of restricted emissions during COVID-19 on air quality in India. Sci Total Environ 728: 138878. https://doi.org/10.1016/j.scitotenv.2020.138878

Shehzad K, Sarfraz M, Shah SGM (2020) The impact of COVID-19 as a necessary evil on air pollution in India during the lockdown. Environ Pollut 266:1-5. https://doi.org/10.1016/j.envpol.2020. 115080

Shi P, Dong Y, Yan H, Zhao C, Li X, Liu W, He M, Tang S, Xi S (2020) Impact of temperature on the dynamics of the COVID-19 outbreak in China. Sci Total Environ 728:138890. https://doi.org/10.1016/j. scitotenv.2020.138890

Sobral MFF, Duarte GB, da Penha Sobral AIG, Marinho MLM, de Souza Melo A (2020) Association between climate variables and global transmission oF SARS-CoV-2. Sci Total Environ 729:138997. https://doi.org/10.1016/j.scitotenv.2020.138997

Tobías A, Carnerero C, Reche C, Massagué J, Via M, Minguillón MC, Alastuey A, Querol X (2020) Changes in air quality during the lockdown in Barcelona (Spain) one month into the SARS-CoV-2 epidemic. Sci Total Environ 726:138540. https://doi.org/10.1016/j. scitotenv.2020.138540

Tosepu R, Gunawan J, Effendy DS, Ahmad LOAI, Lestari H, Bahar H, Asfian P (2020) Correlation between weather and Covid-19 pandemic in Jakarta, Indonesia. Sci Total Environ 725:138436. https://doi.org/10.1016/j.scitotenv.2020.138436

Travaglio M, Popovic R, Yu Y et al (2020) Links between air pollution and COVID-19 in England. medRxiv 2020.04.16.20067405. https://doi.org/10.1101/2020.04.16.20067405

Wang M, Jiang A, Gong L et al (2020) Temperature significant change COVID-19 Transmission in 429 cities. medRxiv. https://doi.org/10. $1101 / 2020.02 .22 .20025791$

Wang Q, Wu N (2012) Long-run covariance and its applications in cointegration regression. Stata J 12:515-542. https://doi.org/10. $1177 / 1536867 \times 1201200312$

WAQI (2020) COVID-19 worldwide air quality data. https://aqien.org/ data-platform/covid19/. Accessed 1st July 2020

Westerlund J (2007) Testing for error correction in panel data. Oxf Bull Econ Stat 69:709-748. https://doi.org/10.1111/j.1468-0084.2007. 00477.x
WHO (2020) Archived: WHO timeline - COVID-19. In: World Heal. Organ. https://www.who.int/news-room/detail/27-04-2020-whotimeline\%2D\%2D-covid-19. Accessed 10th July 2020

Wooldridge JM (2002) Econometric analysis of cross section and panel data. MIT press, Cambridge, Massachusetts

Worldometer (2020) Covid-19 coronavirus pandemic. In: Worldometer. https://www.worldometers.info/coronavirus/? Accessed 6th September 2020

Wu Y, Jing W, Liu J, Ma Q, Yuan J, Wang Y, du M, Liu M (2020b) Effects of temperature and humidity on the daily new cases and new deaths of COVID-19 in 166 countries. Sci Total Environ 729: 139051. https://doi.org/10.1016/j.scitotenv.2020.139051

Wu X, Nethery RC, Sabath BM et al (2020a) Exposure to air pollution and COVID-19 mortality in the United States. medRxiv 2020.04.05.20054502. https://doi.org/10.1101/2020.04.05. 20054502

Xie J, Zhu Y (2020) Association between ambient temperature and COVID-19 infection in 122 cities from China. Sci Total Environ 724:138201. https://doi.org/10.1016/j.scitotenv.2020.138201

Xu K, Cui K, Young LH, Wang YF, Hsieh YK, Wan S, Zhang J (2020) Air quality index, indicatory air pollutants and impact of covid-19 event on the air quality near central china. Aerosol and Air Quality Research, 20(6):1204-1221. https://doi.org/10.4209/aaqr.2020.04. 0139

Zangari S, Hill DT, Charette AT, Mirowsky JE (2020) Air quality changes in New York City during the COVID-19 pandemic. Sci Total Environ 742:140496. https://doi.org/10.1016/j.scitotenv.2020. 140496

Zhu L, Liu X, Huang H et al (2020a) Meteorological impact on the COVID-19 pandemic: a study across eight severely affected regions in South America. Sci Total Environ 744. https://doi.org/10.1016/j. scitotenv.2020.140881

Zhu Y, Xie J, Huang F, Cao L (2020b) Association between short-term exposure to air pollution and COVID-19 infection: evidence from China. Sci Total Environ 727:138704. https://doi.org/10.1016/j. scitotenv.2020.138704

Zoran MA, Savastru RS, Savastru DM, Tautan MN (2020) Assessing the relationship between surface levels of PM2.5 and PM10 particulate matter impact on COVID-19 in Milan, Italy. Sci Total Environ 738: 139825. https://doi.org/10.1016/j.scitotenv.2020.139825

Publisher's Note Springer Nature remains neutral with regard to jurisdictional claims in published maps and institutional affiliations. 